\title{
Prediksi Kepuasan Mahasiswa dengan Menggunakan Algoritma C4.5 terhadap Pelayanan Akademik
}

\author{
Anief Rufiyanto ${ }^{1}$, Muhammad Rochcham ${ }^{2}$, Abdul Rohman ${ }^{3}$ \\ 1,Teknik Elektronika, Universitas Pandanaran, e-mail: aniefrufiyanto@gmail.com \\ 2,Teknik Elektronika, Universitas Pandanaran, e-mail: muhrochan@gmail.com \\ ${ }^{3}$ Teknik Informatika Universitas Ngudi Waluyo, e-mail: abdulrohman15@gmail.com
}

\section{ARTICLE INFO}

Article history:

Received 02 October 2020

Received in revised form 22 October 2020

Accepted 03 January 2021

Available online 31 January 2021

\begin{abstract}
Prediction of student satisfaction with academic services needs to be done to evaluate the performance of higher education institutions in the academic field, especially at Pandanaran University. In this study, using the data mining algorithm Decision Tree C4.5 method in classifying student data through a questionnaire on the aspects of tangible, reliability, assurance, responsiveness and empathy. The results of classifying student data using the Decision Tree C4.5 algorithm produce a decision tree model with an accuracy value of $87.92 \%$ and an AUC of 0.990 so that it is classified as very good data.
\end{abstract}

Keywords: Satisfaction, Student, Decision Tree, C4.5

\section{Pendahuluan}

Dengan pesatnya perkembangan dan persaingan lembaga pendidikan terutama pendidikan tinggi swasta diperlukan peningkatan pelayanan akademik, sehingga menimbulkan tingkat kepercayaan dan kepuasan masyarakat yang baik terhadap perguruan tinggi tersebut. Universitas Pandanaran merupakan perguruan tinggi swasta yang berada di semarang berdiri tahun 1996 memiliki persentase jumlah mahasiswa yang naik turun atau tidak stabil dalam beberapa tahun ini. Salah satu yang menyebabkan hal tersebut adalah pelayanan akademiknya.

Dalam penelitian ini, peneliti ingin mengetahui prediksi kepuasan mahasiswa terhadap layanan akademik dengan menggunakan metode klasifikasi data mining algoritma Decision Tree C4.5, sehingga hasil model pohon keputusan dan aplikasinya dapat dimanfaatkan untuk keperluan evaluasi kebijakan perguruan tinggi.

\section{Metode Penelitian}

Dalam penelitian tentang prediksi kepuasan mahasiswa terhadap layanan akademik tidak terlepas dari 5 aspek yaitu; tangible, reability, assurance, responsiveness dan empathy untuk menilai mutu layanan dalam sebuah organisasi [1],[2]

Algoritma C4.5 merupakan jenis metode klasifikasi data mining Decision Tree yang dapat menghasilkan model pohon keputusan yang baik, yang konsisten dari sekumpulan data [3,][4],[5],[6],[7]. Dengan model tersebut dapat diterapkan dalam perangkat lunak. 
Dalam perhitungannya, Algoritma C4.5 menggunakan entropy, gain, split information dan gainratio untuk pemilihan atribut menjadi node [6], yaitu:

$$
\begin{gathered}
\operatorname{Entropy}(i)=\sum_{j=1}^{m} f(i, j), 2 f[(i, j)] \\
\text { Gain }=-\sum_{i=1}^{p}{ }_{n}^{n i} \operatorname{IE}(i) \\
\text { Split Information }=-\sum_{t=1}^{c} \frac{s 1}{s} \log _{1} \frac{s 1}{s} \\
\operatorname{Gainratio}(S . A)=\frac{\operatorname{Gain}(\operatorname{S.A})}{\operatorname{SplitInformation}(S . A)}
\end{gathered}
$$

Tahap awal dalam penelitian ini, adalah mengolah data kuesioner mahasiswa tentang kepuasan terhadap layanan akademik di Universitas Pandanaran. Ada 5 Aspek dalam kuesioner tersebut yaitu; tangible (bukti fisik), reability (kehandalan), assurance (jaminan), responsiveness(ketanggapan) dan empathy (memberikan perhatian yang tulus). Dan tiap-tiap aspek tersebut di kemas dalam sebuah pertanyaan/pernyataan.

Menurut data di bidang akademik dan bidang keuangan di Universitas Pandanaran, mahasiswa aktif sampai semester genap 2019/2020 berjumlah 698 mahasiswa. Maka sampel yang akan diambil sebanyak 248 mahasiswa, yang berdasarkan kesalahan 5\% dan kepercayaan $95 \%$ dari populasi [8].

Untuk mencapai tujuan penelitian, maka kerangka pemikiran penelitian ini adalah:

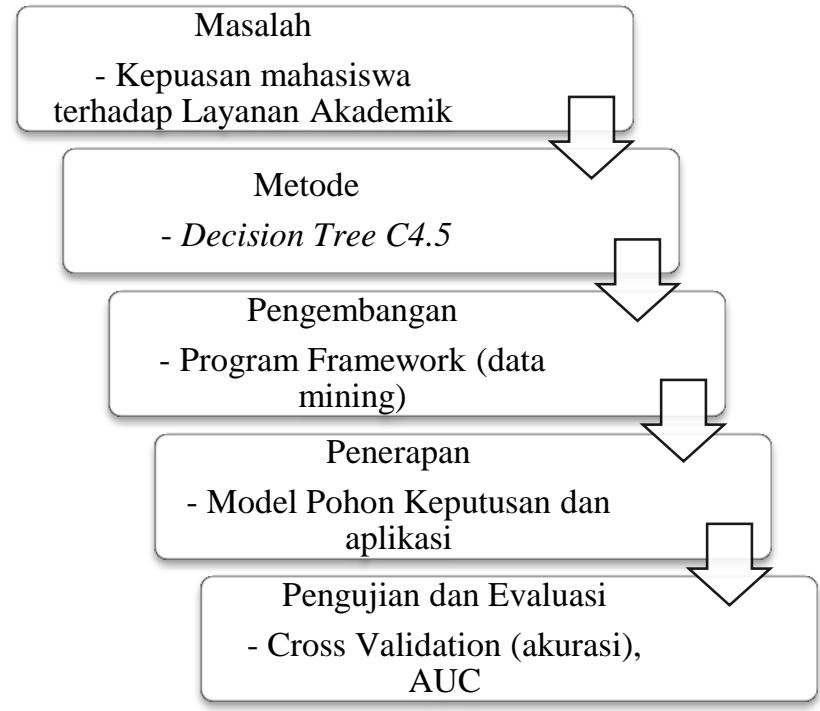

Gambar 1. Kerangka Pemikiran 
Dataset yang dihasilkan dari hasil pengolahan kuesioner adalah sebagai berikut:

\begin{tabular}{|c|c|c|c|c|c|c|}
\hline NO & TANGIBLES & REALIBILITY & RESPONSIVENESS & ASSURANCE & EMPATHY & HASIL \\
\hline 1 & TINGGI & TINGGI & TINGGI & TINGGI & TINGGI & PUAS \\
\hline 2 & TINGGI & TINGGI & RENDAH & RENDAH & RENDAH & TIDAK PUAS \\
\hline 3 & TINGGI & TINGGI & TINGGI & TINGGI & TINGGI & PUAS \\
\hline 4 & TINGGI & TINGGI & TINGGI & TINGGI & TINGGI & PUAS \\
\hline 5 & TINGGI & TINGGI & TINGGI & TINGGI & TINGGI & PUAS \\
\hline 6 & TINGGI & TINGGI & TINGGI & TINGGI & TINGGI & PUAS \\
\hline 7 & TINGGI & TINGGI & TINGGI & TINGGI & TINGGI & PUAS \\
\hline 8 & TINGGI & TINGGI & TINGGI & TINGGI & TINGGI & PUAS \\
\hline 9 & TINGGI & TINGGI & TINGGI & TINGGI & TINGGI & PUAS \\
\hline 10 & TINGGI & TINGGI & TINGGI & TINGGI & TINGGI & PUAS \\
\hline 11 & TINGGI & TINGGI & TINGGI & TINGGI & TINGGI & PUAS \\
\hline 12 & TINGGI & TINGGI & TINGGI & TINGGI & TINGGI & PUAS \\
\hline 13 & TINGGI & TINGGI & TINGGI & TINGGI & TINGGI & PUAS \\
\hline 14 & TINGGI & TINGGI & TINGGI & TINGGI & TINGGI & PUAS \\
\hline 15 & TINGGI & TINGGI & TINGGI & TINGGI & TINGGI & PUAS \\
\hline 16 & TINGGI & TINGGI & TINGGI & TINGGI & TINGGI & PUAS \\
\hline 17 & TINGGI & TINGGI & TINGGI & TINGGI & TINGGI & PUAS \\
\hline 18 & TINGGI & TINGGI & TINGGI & TINGGI & TINGGI & PUAS \\
\hline 19 & TINGGI & TINGGI & TINGGI & TINGGI & TINGGI & PUAS \\
\hline 20 & TINGGI & TINGGI & RENDAH & TINGGI & TINGGI & TIDAK PUAS \\
\hline 21 & TINGGI & TINGGI & TINGGI & TINGGI & TINGGI & PUAS \\
\hline 22 & TINGGI & TINGGI & RENDAH & TINGGI & TINGGI & TIDAK PUAS \\
\hline 23 & TINGGI & TINGGI & TINGGI & TINGGI & TINGGI & PUAS \\
\hline 24 & RENDAH & TINGGI & RENDAH & TINGGI & TINGGI & TIDAK PUAS \\
\hline 25 & TINGGI & TINGGI & TINGGI & TINGGI & TINGGI & PUAS \\
\hline 26 & TINGGI & TINGGI & TINGGI & TINGGI & TINGGI & PUAS \\
\hline 27 & TINGGI & TINGGI & TINGGI & TINGGI & TINGGI & PUAS \\
\hline 28 & TINGGI & TINGGI & TINGGI & TINGGI & TINGGI & PUAS \\
\hline 29 & TINGGI & TINGGI & TINGGI & TINGGI & TINGGI & PUAS \\
\hline 30 & TINGGI & TINGGI & TINGGI & TINGGI & TINGGI & PUAS \\
\hline
\end{tabular}

\section{Hasil dan Pembahasan}

Dari dataset 248 mahasiswa terdapat hasil kepuasan yaitu; dengan PUAS berjumlah 205 mahasiswa dan TIDAK PUAS berjumlah 43 mahasiswa. Maka data tersebut di klasifikan dengan metode Decision Tree C4.5, dengan training data dan test data untuk mengestimimasi ketepatan dari rule dan model klasifikasi pohon keputusan [7].

Dari klasifikasi dataset tersebut diatas, menghasil model pohon keputusan sebagai berikut:

TRANSFORMATIKA Vol.18, No.2, January 2021: 210-214 


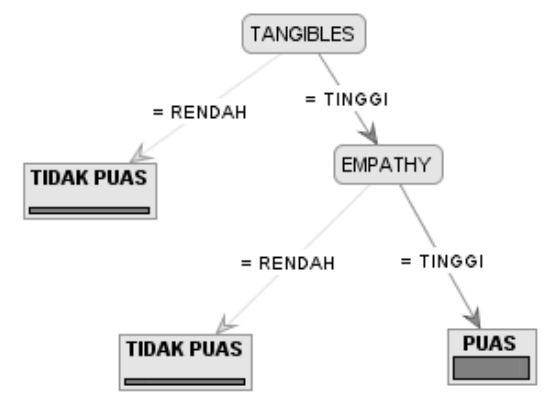

Gambar 2. Model Pohon Keputusan Kepuasan Mahasiswa terhadap Pelayanan Akademik

Sesuai dengan model pohon keputusan kepuasan mahasiswa terhadap pelayanan akademik di Universitas Pandanaran, maka dapat di buatkan rule [9] berjumlah 3 yaitu sebagai berikut:

1. Jika Trangibles $=$ rendah maka mahasiswa tidak puas

2. Jika Trangibles $=$ tinggi, dan Empathy $=$ rendah, maka mahasiswa tidak puas

3. Jika Trangibles $=$ tinggi, dan Empathy $=$ tinggi maka mahasiswa puas

Dengan dasar rule tersebut diatas, maka dapat dibuatkan program atau aplikasi komputer prediksi kepuasan mahasiswa terhadap pelayanan akademik di Universitas Pandanaran, yaitu seperti gambar dibawah ini:

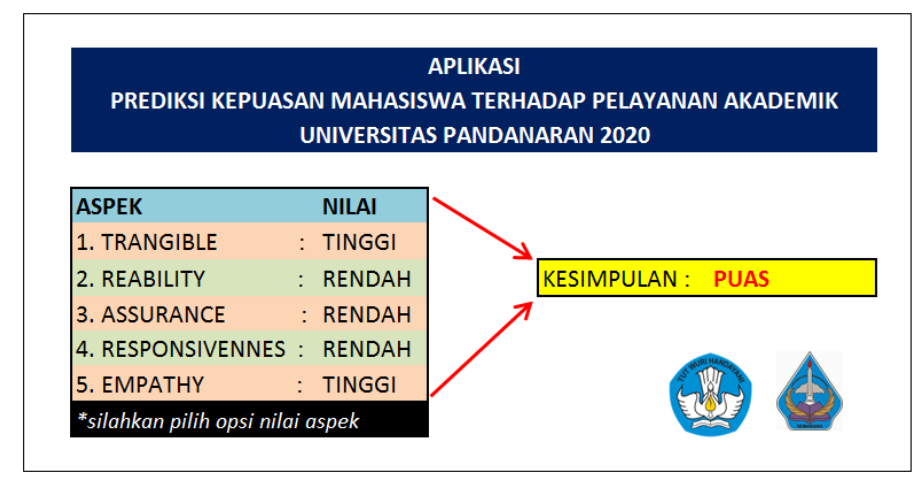

Gambar 2. Aplikasi Prediksi Kepuasan Mahasiswa terhadap Layanan Akademik

Setelah menghasilkan model pohon keputusan, rule dan aplikasi prediksinya dengan menggunakan algoritma Decision Tree C4.5, maka langkah selanjutnya adalah pengujian dengan cross validation atau tingkat akurasi dan evaluasi dengan AUC (Area Under Curve) [10].

Hasil akurasinya adalah 87,95\% dan AUC nya sebesar 0,990. Karena 0,995 terdapat dalam kategori 0,90 - 1,00 maka klasifikasi dataset ini termasuk klasifikasi sangat baik [10].

\section{Kesimpulan}

Penelitian prediksi kepuasan mahasiswa terhadap pelayanan akademik di Universitas Pandanaran ini, dengan menggunakan metode klasifikasi data mining algoritma Decision Tree C4.5 menghasilkan model, rule dan aplikasi prediksi kepuasan mahasiswa dengan nilai akurasi 87,95\% dan nilai AUC 0,995 sehingga termasuk klasifikasi data sangat baik. Karena dalam penelitian ini hanya atribut trangible dan empathy yang sangat berpengaruh dalam menentukan kepuasan mahasiswa, maka perlu dioptimalkan dalam dataset dengan berbagai angkatan.

Prediksi Kepuasan Mahasiswa dengan Menggunakan Algoritma C4.5 terhadap Pelayanan Akademik (Anief Rufiyanto) 


\section{Daftar Pustaka}

[1] Oktafianto, 2016, Analisis Kepuasan Mahasiswa Terhadap Pelayanan Akadmik Menggunakan Metode Algoritma C4.5, Jurnal TIM Darmajaya, vol 02, no.01 hal 1-11.

[2] Budi Prijanto, Agustin Rusiana Sari, 2011, Analisis Tingkat Kepuasan Mahasiswa atas Layanan Akademik Berbasis Web, Prosiding Konferensi Nasional Sistem Informasi, Medan 25-26 Februari 2011

[3] Budi Santoso, 2007, Data Mining Teknik Pemanfaatan Data Untuk Keperluan Bisnis, Graha Ilmu, Yogyakarta.

[4] Eko Prasetyo, 2014, Data Mining Mengolah Data Menjadi Informasi Menggunakan Matlab, Penerbit Andi, Yogyakarta.

[5] Suyanto, 2019, Data Mining Untuk Klasifikasi dan Klasterisasi Data Edisi Revisi, Informatika, Bandung.

[6] Joko Suntoro, 2019, Data Mining Algoritma dan Implementasi dengan Pemrograman PHP, Elex Media Komputindo, Jakarta.

[7] Retno Tri Vulandari, 2017, Data Mining Teori dan Aplikasi Rapidminer, Gava Media, Yogyakarta.

[8] Sugiyono, 2002, Statistia Untuk Penelitian, Alfabeta, Bandung

[9] Witten, 2007, Data Mining Complications: Overfitting Statistical modeling one atribut does all the work, Margan Kaufmann Publisher, Burlington.

[10] Gorunnesco, 2011, Data mining: concepts, model and techques, Springer, Berlin. 